\begin{tabular}{|c|c|}
\hline \multirow{3}{*}{ 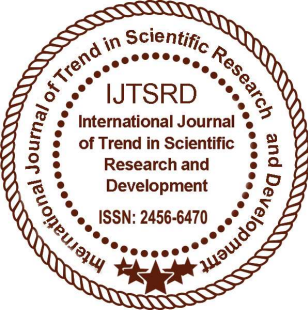 } & $\begin{array}{l}\text { International Journal of Trend in Scientific } \\
\text { Research and Development (IJTSRD) }\end{array}$ \\
\hline & International Open Access Journal \\
\hline & ISSN No: 2456 - 6470 | www.ijtsrd.com | Volume - 2 | Issue - 4 \\
\hline
\end{tabular}

\title{
Synergies Created by Strategic Fit Between Business Strategies and Human Resource Strategies in Transnational Tea Firms in Kenya
}

\author{
Dr. Charles Mulandi Zakayo \\ Senior Lecturer, School of Business and Economics, Kabarak University, Nakuru, Kenya
}

\section{ABSTRACT}

Business strategies that are formulated and implemented by many organizations in Kenya do not significantly enhance their performance. This could be due to lack of strategic fit between business strategies and Human Resource strategies in these firms. Therefore this study was conducted to establish the synergies created by strategic fit between Business strategies and Human resource strategies in Transnational tea firms in Kenya. The study was guided by the following specific objectives:- To determine business strategies and Human Resource strategies applied by Transnational tea firms in Kenya and the synergies created by the fit between them. The study adopted descriptive research design. The targeted population comprised of 20 strategic managers and 7 human resource managers, totaling to 27 respondents. Censor method was applies due to small targeted population. Primary data was collected by use of questionnaires while secondary data was collected from firms' strategic plans, productivity profiles and from inventories. The collected data was analyzed by the help of Statistical Package for Social Sciences (SPSS 12.0). The study found that once business strategies are decided upon, human resource strategies that complement and justify them have to be formulated and implemented. The study established that strategic fit leads to several synergies to the organization among them, enhanced employee commitments, flexibility and improved employee productivity. All these are crucial competitive advantage for an organization. The research recommends that HR strategies need to be explicit and clearly stated. Transnational tea firms in Kenya should outsource the non-core activities and should have a well grafted balance between the use of Tea harvesting machines and handpicking of tea.

Keywords: Synergies, Strategic fit, Out sourcing, Social capital, Human capital

\subsection{INTRODUCTION}

Industries are characterized by trends and new developments that gradually or speedily produce changes that require strategic response from the participating firms. These firms need to identify their distinctive competencies and exploit them effectively to position themselves firmly in the competitive environment. (Thompson and Stricklan, 2003).

Achievement of Corporate objectives requires development of two basic resources i.e, money and people and deficiency of any of these, weakens the best chosen strategy. Many companies fail in formulating and developing human resource strategies which are linked closely to business strategies (Hassey 2000). Human resource practices should be regarded as genuine partner in management team. Organizations can only operate effectively if the right quantity and quality of management and nonmanagement personnel are on board. Human resource strategies are integral part of business strategy therefore they should be developed and aligned with business strategies.

Business and human resource strategies need to be coherent and geared towards achieving organization's competitive advantage. These means there should be a vertical and horizontal fit between human resource strategies and business strategies. Business strategy 
needs to be dove-tailed into the right quality and quantity of human resources. Without attracting and retaining the right personnel with the right skills and training, the organization cannot succeed (US office of personnel management 1999). Human resource strategy ought to influence the corporate strategy and in turn be influenced by it.

In the Tea industry the traditional labour in tea picking is increasingly getting mechanized due to ever increasing wage bill in this sector. These tea firms need to take a strategic view of their human resources due to seasonal nature of their operations and their susceptibility to external phenomenon such as wage rates, foreign exchange rates and fluctuations of international prices. These firms walk on the tight rope of labour and cost.

\subsection{STATEMENT OF THE PROBLEM}

Staff managers and line managers are becoming more aware of the current mantras 'Be strategic and $\mathrm{Be}$ business partner' but how they can be strategic and how they can be business partner has not always been explained. In practice many organizations around the world, emphasize more on business strategies but pay no or little attention to Human resource strategies (Tyson 2006). Dimba and K'Obonyo (2009) carried a study on effects of Strategic Human Resource Management practices on performance of multinational manufacturing companies but none of the tea companies was studied.

Kenya tea firms like most of international organization formulate and implement some business strategies but no study has been carried out to find out whether these firms achieve strategic fit between the business and Human resource strategies and the synergies associated with achieving a strategic fit. Due to the nature of their intensive labor, these firms require major decisions on Human resources. Their labor related costs constitutes up to $60 \%$ of the total cost of production (Task force report on tea industry 2007). It is therefore crucial to make efforts to achieve a strategic fit between the business and Human resource strategies and reap the benefits of this fit. For the organization to enhance its performance there must be a "fit" between a firm's HRM practices and the firm's competitive strategies (Wright and Snell 1998). This study aimed at establishing synergies created by strategic fit between business strategies and HR strategies in Transnational Tea firms in Kenya.

\subsection{SPECIFIC OBJECTIVES OF THE STUDY.}

This study was guided by the following specific objectives:-

1. To establish the major business strategies employed by Transnational tea firms in Kenya.

2. To establish the major Human resource strategies employed in Transnational Tea firms in Kenya

3. To establish the synergies created by strategic fit between business strategies and Human resource strategies in Transnational Tea firms in Kenya.

\subsection{Operational definition of terms.}

Strategic 'fit' is the level at which Human resources and Business strategies are aligned and geared towards achieving the same objectives.

Strategy is a large-scale future oriented plan for interacting with the competitive environment to achieve organizational objective.

Synergy; This is when two or more activities or process complement one another to the extent that when undertaken in unison the total output is significantly greater than when they are done individually i.e, benefits accruing to the organization when Human resource strategies and corporate strategies are consistent with one another are great.

\subsection{Literature}

\subsection{Corporate Strategy.}

Strategic management emphasizes on monitoring and evaluating the external opportunities and threats in light of corporate strength and weakness in order to generate and implement a strategic decision (Hurger and Wheelen 2007). Strategic management is a continuous and interactive process aimed at keeping an organization as a whole appropriately matched to its environment (Certo and Peter 1993). Organization analyzes its external and internal environment $\mathrm{s}$ to determine opportunities, threats, its capabilities and core competencies and this information helps it to develop its vision and mission and then formulate appropriate strategies and implement them accordingly. Strategic management tries to reduce future uncertainty. It focuses on current business landscape and expected future business landscape. Strategy promotes the continuity and viability of the enterprise (White 2007).

For the organization to stand and compete effectively its business strategies must be developed at the same time with its Human Resource strategies. 


\subsection{Business Strategies.}

Business competitive strategies are those strategies that are adopted in order to strengthen the position of the organization in the market. It deals with how to compete in the market, which products or services should be developed and offered to which market and to what extent the organization meets its customer needs, market growth, efficiency and its long term profitability. They provide direction for strategic actions and are the basis for coordinated and sustained efforts directed towards achieving long term business objectives (Pearce and Robbinson 2009. A firm can obtain high returns in an industry despite the presence of strong competitive forces if it concentrates on overall cost leadership. Business uses strategies like cost-cutting, improved quality products and services, speeding operations and streamlining operations in order to create a leaner, flatter and faster organization by eliminating unnecessary levels of work or nonvalue adding activities (Malik 2006). Business level strategies indicate the choice the firm has made about how it intends to compete in a niche market, i.e gaining competitive advantage by exploiting core competencies (Ireland et al 2009)

\subsection{Human Resource Strategies}

The process of developing HR strategies involves the adoption of a contingent approach in generating strategic HRM option and thus making appropriate strategic choices. The HR strategy of an organization must be contingent to the need and circumstances of that organization. The actual strategic elements depend on the requirement and context of the organization (Cappelli (1999), Astrong and Baran 2002). Human resource strategy formulation process starts with defining the business strategy, identifying the business needs to be achieved by human resource strategy, defining the specific human resource strategies to be implemented and finally preparing and implementing the action plans. Quality and quantity of workforce is necessary.

\subsection{Approaches to Strategic Human Resource Management}

There are various approaches to strategic HRM such as Best practice Approach, Best fit approach and configuration approach (Armstrong and Baron 2006). Best practice approach is based on the belief that there is a set of best human resource management practices and that, adopting them will lead to superior organizational performance (Armstrong and Baran 2006). The best known set is the Pfeffer's (1994) list of the seven human resource practices of successful organizations:- employment, security, self managed team, high compensation based on performance, training , flatter organizational structure and information sharing for better performance. There is need for Human resource practitioners to become more embedded in their organization's strategic process so that their offerings are more strategically integrated.

The Best fit approach holds that the aim of SHRM is to provide a fit between goals of the HRM and those of the business. The HR strategy must be contingent to the needs and circumstances of the organization (Guest 1989).

Configuration school draws attention to three beliefs:Strategies may vary according to life circle of the organization, secondly, they depend on the sector of organization and thirdly, they are about change and transformation (Burcell , 2001).

\subsection{Human Resource Linkage and integration}

Strategic implementation involves the activities and choices required for the execution of a strategic plan (Huger \& Wheelen 2007). Successful strategy implementation depends upon the managers' skills of working through others, organizing, motivating, culture building and realizing a strong fit between strategy and how organization does things. Line management and HR professionals need to cultivate an atmosphere in which employees would willingly and enthusiastically work towards the attainment of business strategy. HR professionals must align HR policies and practices with vision, mission and values, help line managers and other employees understand the importance of organizational culture and develop HR practices that send a clear and consistent message about the desired culture. Employees have to focus their efforts on contributing to the mission of the organization, seek to understand organizational culture and values, adapt to changing conditions, learn which behaviors are needed and develop skills needed for strategy implementation. Companies have to prepare their people for the changes they are about to undergo (Jackson \& Schuler 2001). HR issues are the major part of any strategic change efforts. Therefore HR planning and business planning should be integrated. Various HR functions that add value to the organization should be determined (Nel \& Warnes 2004). The future of HRM in terms of creating value lies on agility and ability of the systems to develop an 
agile and flexible work-force (Dyer \& Erickson 2005).

\subsection{Employee Commitment}

HRM contributes to business strategy by shaping the core competencies of the organization. These competencies are enhanced by developing employee skills (human capital) and by increasing trustful interaction between employees (social capital). Social capital encourages more effective coordination and innovation through sharing knowledge via informal networks based on trust. Trust leads to high commitment which in turn leads to organizational high performance.

\subsection{HR development}

To manage the organization effectively there should be a clear link between organizational objectives and human capital. This is achieved through developing human capital base in the organization. Human capital base is developed through continuous human resource development (Katon \& Budhwar 2006).

\subsection{Kenya Tea Firms- Strategic Concerns.}

Agricultural sector contributes to $70 \%$ of the total employment in Kenya and $19 \%$ of formal wage workers in Kenya are in agriculture. Kenya firms export semi-processed low value produce due to limited ability to add value to agricultural produce. Kenyan tea is largely exported in bulky and semiprocessed. It is auctioned through Mombasa and major buyers are foreigners. Average global auction prices have been declining drastically (Task-force Report on Tea industry 2007). Kenya tea firms have the highest production cost in Africa due to high cost labour. This industry is now recognizing the needs to re-evaluate itself and make a strategic shift in order to remain profitable and globally competitive. Therefore there is need to establish a fit between business strategy and human resource strategy and align them to promote effectiveness and efficiency in tea industry.

\subsection{Conceptual framework}

Independent variables

Dependant variables

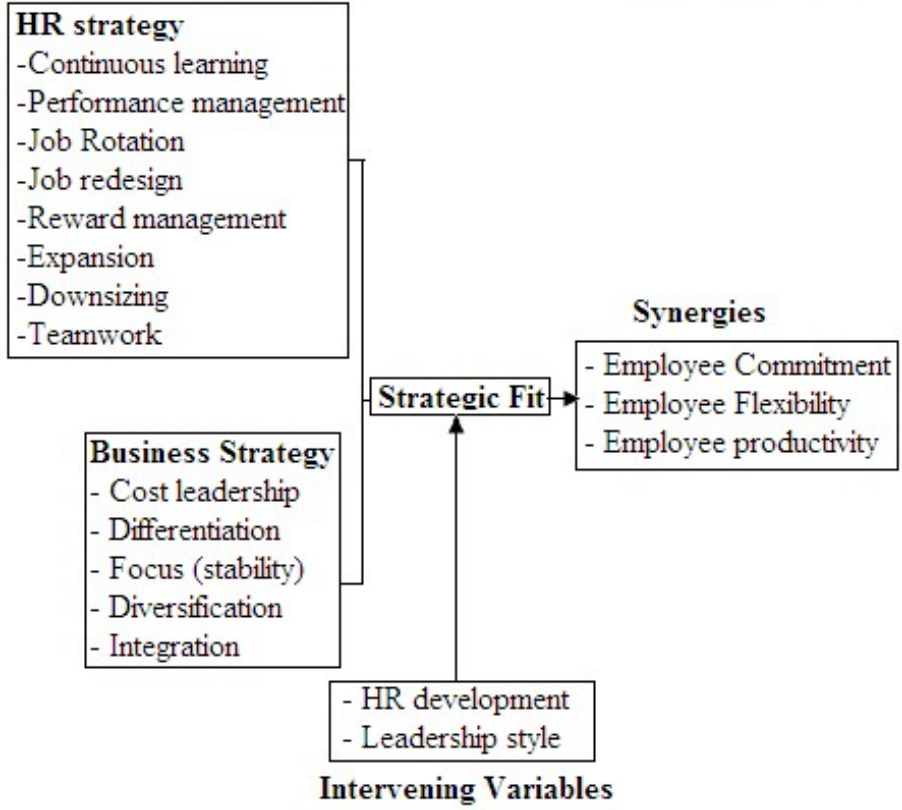

\subsection{Research Methodology}

The study applied descriptive research design and targeted the seven Transnational Tea firms operating in Kenya. These included Unilever Tea Kenya ltd, Finlays Kenya ltd, Eastern produce ltd, and Williamson tea Kenya ltd, Sotik Tea Estates ltd, Kipkebe ltd and Nandi Tea estate. The respondents were the managers of the 20 strategic Business units and 7 managers in charge of human resource functions. Total 27 respondents.

Table: Target population

\begin{tabular}{|l|l|l|l|}
\hline Tea firms & $\begin{array}{c}\text { Strategic } \\
\text { Business } \\
\text { Units } \\
\text { managers }\end{array}$ & $\begin{array}{c}\text { Human } \\
\text { resource } \\
\text { managers }\end{array}$ & Total \\
\hline Unilever & 4 & 1 & 5 \\
\hline Finlays & 3 & 1 & 4 \\
\hline $\begin{array}{l}\text { Eastern } \\
\text { produce }\end{array}$ & 4 & 1 & 5 \\
\hline Williamson & 4 & 1 & 5 \\
\hline Sotik & 2 & 1 & 3 \\
\hline Kipkebe & 2 & 1 & 3 \\
\hline Nandi & 1 & 1 & 2 \\
\hline Total & 20 & 7 & 27 \\
\hline
\end{tabular}

Since the targeted population was small, the researcher subjected the entire population of 27 managers to the study. Secondary data was obtained from firms' publications and strategic documents. Primary data was collected by use of questionnaire. 
The validity and reliability of the questionnaires were tested before they were used to collect primary data from respondents.

\subsection{Data analysis, interpretation and presentation}

Statistical Package for Social Sciences (SPSS 12.0) program was applied.

Data was analyzed using descriptive and inferential statistics. Descriptive statistics such as mean, percentages and frequencies were applied. Pearson's product moment correlation coefficient was calculated to determine the level of fit between the business and HR strategies and results reported cumulatively except instances where comparisons or unique findings needed to be singled out. The response rate was $100 \%$.

\subsection{Business strategies}

The first objective was to determine the business strategies employed by Transnational tea firms in Kenya. The study found that cost leadership strategy, differentiation strategy, focus strategy, horizontal integration strategy, vertical integration strategy and diversification strategies were applied in Transnational tea firms in Kenya but in varying degree. This indicate that keeping cost at lowest possible level is the most important overall strategy for these organizations bearing in mind that these firms do not determine the price of the tea but is determined by the tea brokers at auction.

\subsection{Generic business strategies}

The study identified three generic business strategies applied in Transnational tea firms in Kenya namely; cost leadership strategy $60 \%$, differentiation strategy $20 \%$ and focus strategy $20 \%$.

\begin{tabular}{|l|r|r|}
\hline Generic strategy & Frequency & percentage \\
\hline Cost leadership & 12 & 60 \\
\hline Differentiation & 4 & 20 \\
\hline Focus & 4 & 20 \\
\hline Total & 20 & 100 \\
\hline
\end{tabular}

This indicated that keeping cost at the lowest level possible is the central interest of Transnational tea firms in Kenya.

Other strategies were:-

\section{A. Horizontal integration}

This is the combination of firms operating in the same industry and at the same stage of production/distribution chain. The findings showed that horizontal integration has some importance in transnational tea firms as $35 \%$ of them were engaged in it.

\section{B. Vertical integration}

The study found that $60 \%$ of these firms were engaged on vertical integration. This was done by growing and transporting green leaf tea to their own factories instead of buying from other tea growers. Some have established tea brokerage firms to ensure better bargaining power leading to better prices for their products.

\section{Diversification}

The study found that majority of these firms did not see the importance of diversification. Only $25 \%$ of the total firms had diversified into other products like, flowers, tree growing etc.

Factors affecting successful implementation of strategies in Transnational tea firms.

The study found that successful implementation of business strategies in these tea firms was affected by:Weather patterns, dollar/shilling exchange rates, international tea prices, labour wages and technological changes. Dollar/shillings exchange rate, international tea prices and weather pattern influence to a greater extend the success in implementation of strategies $(70 \%)$.

\subsection{Human resource strategies}

The second objective of the study was to determine the human resource strategies employed by transnational tea firms in Kenya. The essence of determining these strategies was to correlate them with the business strategies. The study found that human resource strategies;- continuous learning, performance management, job redesigning, job rotation, reward management, teamwork and downsizing were employed in these tea firms but in varying degree. Continuous learning 90\%, performance management $86 \%$, reward management $86 \%$, downsizing $75 \%$, teamwork $70 \%$, Job rotation $43 \%$ and job redesigning $14 \%$. The study found that these tea firms were not using recruitment as one of their HR strategies. These firms were not expanding the quantity of their work-force.

\subsection{Strategic Fit}

The third objective of the study was to establish the strategic fit between business strategies and human 
resource strategies employed by Transnational tea firms in Kenya.

In order to evaluate the existence of strategic fit, Pearson's product moment correlation coefficient (r) was calculated for each business strategy against each HR strategy. The findings were;-

\section{A. Strategic fit between Cost leadership and related HR strategies}

The findings of the study showed positive strategic fit between cost leadership and related various HR strategies;- performance management $(\mathrm{r}=0.850)$, reward management $(\mathrm{r}=0.888)$ and downsizing $(\mathrm{r}=$ $0.800)$. At the same time it showed a strong negative relationship with recruitment $(\mathrm{r}=-0.850)$.

B. Strategic Fit between Differentiation and related human resource strategies.

The study showed positive strategic Fit between differentiation and the following HR strategies;continuous learning $(\mathrm{r}=0.838)$, job redesigning $(\mathrm{r}=0.888)$ but it

showed a strong negative relationship with recruitment $(\mathrm{r}=-0.850)$.

\section{Strategic fit between Diversification and HR Strategies}

The study found strategic fit between diversification and related HR strategies. It showed a strong positive correction between job redesign $(\mathrm{r}=0.974)$, job rotation $(\mathrm{r}=0.932)$, performance management $(\mathrm{r}=$ $0.908)$, teamwork $(\mathrm{r}=0.994)$ and reward management $(\mathrm{r}=0.928)$

\section{Strategic Fit between vertical integration and related HR strategies}

The study showed a strategic fit between vertical integration and related HR strategies.

Vertical integration had strong positive relationship with job rotation $(r=0.824)$ and job

redesign $(\mathrm{r}=0.595)$

\section{E. Strategic Fit between Horizontal integration and related $H R$ strategies}

The study found strong positive relationship with job redesign $(\mathrm{r}=0.957)$ and job rotation $(\mathrm{r}=0.957)$ and weak relationship with recruitment $(\mathrm{r}=0.044)$

\section{F. Synergies created by strategic Fit}

The main objective of this study was to identify the synergies created by strategic fit between business strategies and human resource strategies. In order to test for synergies created by strategic Fit the study made use of multiple regression by setting up three models representing the prediction of strategic fit on each of the three broad categorization of synergies ;employees commitment, employees flexibility and employees productivity.

\subsection{Regression results for relationship between strategic Fit and employee commitment} The table below shows multiple regression analysis of the prediction of employee commitment.

A. model summary

\begin{tabular}{|l|l|l|l|l|}
\hline Model & $\mathbf{R}$ & $\mathbf{R}$ squared & adjusted R & Std Error of the estimates \\
\hline 1 & $0.985(\mathrm{a})$ & 0.97 & 0.851 & 4.31991 \\
\hline
\end{tabular}

B. Anova

\begin{tabular}{|l|l|l|l|l|l|l|}
\hline \multicolumn{1}{|c|}{ Model } & \multicolumn{1}{c|}{$\begin{array}{c}\text { sum of } \\
\text { squares }\end{array}$} & df & mean square & F & sig \\
\hline \multirow{3}{*}{1} & Regression & 606.672 & 4 & 151.668 & 8.127 & $.037(\mathrm{a})$ \\
\cline { 2 - 7 } & Residual & 18.662 & 1 & 18.662 & & \\
\cline { 2 - 7 } & Total & 625.333 & 5 & & & \\
\hline
\end{tabular}


International Journal of Trend in Scientific Research and Development (IJTSRD) ISSN: 2456-6470

C. Coefficients (a)

\begin{tabular}{|c|c|c|c|c|c|c|c|c|c|c|}
\hline \multirow[t]{2}{*}{ Model } & & \multicolumn{2}{|c|}{$\begin{array}{l}\text { Un- } \\
\text { standardized } \\
\text { coefficients }\end{array}$} & \multirow{2}{*}{$\begin{array}{l}\text { standardized } \\
\text { coefficients } \\
\text { Beta }\end{array}$} & \multirow[t]{2}{*}{$\mathbf{T}$} & \multirow[t]{2}{*}{ Sig } & \multicolumn{2}{|c|}{$\begin{array}{l}95 \% \text { confidence } \\
\text { interval for } B\end{array}$} & \multicolumn{2}{|c|}{$\begin{array}{l}\text { Collinearity } \\
\text { statistics }\end{array}$} \\
\hline & & B & $\begin{array}{l}\text { Std } \\
\text { error }\end{array}$ & & & & $\begin{array}{l}\text { lower } \\
\text { Bound }\end{array}$ & $\begin{array}{l}\text { upper } \\
\text { bound }\end{array}$ & Tolerance & VIF \\
\hline \multirow[t]{5}{*}{1} & Constant & 13.171 & 9.75 & & 1.351 & 0.006 & 137.037 & 110.714 & & \\
\hline & Focus & 0.052 & 0.151 & 0.08 & 0.345 & 0.009 & -1.869 & 1.973 & 0.554 & 1.805 \\
\hline & $\begin{array}{l}\text { Continuous } \\
\text { Learning } \\
\end{array}$ & 0.368 & 0.302 & 0.392 & 1.219 & 0.037 & -3.467 & 4.203 & 0.289 & 3.464 \\
\hline & $\begin{array}{l}\text { Perform } \\
\text { ance mgt }\end{array}$ & 0.305 & 0.481 & 0.177 & 0.634 & 0.04 & -5.809 & 6.419 & 0.381 & 2.622 \\
\hline & Teamwork & 0.456 & 0.134 & 0.944 & 3.4 & 0.012 & -1.248 & 2.16 & 0.387 & 2.583 \\
\hline
\end{tabular}

Dependant variable: Employee commitment

“Variables representing strategic fit between business strategy (focus) and HR strategies (continuous learning, performance management and teamwork)".

The model shows that $\mathrm{R}$ squared is 0.97 . This means that $97 \%$ of the variation in employee commitment is caused by independent variables. Since $\mathrm{F}=8.127$ with df $=5$ and $\mathrm{p}=0.037$ Focus, continuous learning, performance management and teamwork are statistically significant predictors of employee commitment. Beta coefficient for all the independent variables are;- focus (0.08), continuous learning $(0.392)$, performance management $(0.177)$ and teamwork (0.944), $\mathrm{p}<0.05$. This is an indication that strategic Fit has a positive and direct impact on employee commitment.

To assess whether multicollinearity of the independent variables was a problem, tolerance were computed. Tolerance is the value of collinearity. A value under 0.2 usually means the variable is correlating with other independent variables and multicollinearity is therefore a threat. In this case the tolerance figures were:- focus (0.554), continuous learning (0.289), performance management $(0.381)$ and teamwork (0.387).This indicated absence of multillinearity.

\subsection{Relationship between strategic HR integration and employees productivity}

The tables given below presents multiple regression analysis of the prediction of employee productivity by two independent variables representing HR integration (i.e linking of different aspects of HRM especially performance management and reward management with productivity. The model shows that R squared is 0.601 which means that $60.1 \%$ of the variations in employee productivity is caused by the independent variables. $\mathrm{F}=2.257$ with $\mathrm{df}=5$ and $\mathrm{p}=0.002$. Reward management and performance

management are statistically significant predictors of employee productivity. The beta coefficient for independent variables, performance management is $(0.563)$ and reward management is $(0.372, p<0.05$. It is accepted that HR integration has a positive and direct impact on employee productivity. To assess whether multicollinearity of the independent variables was a problem, tolerances were computed. The tolerance figures were both above the threshold value of 0.2. Variance inflation factors (VIFs) were computed and non of the VIFs approached the threshold value of 10 . Therefore there was no serious multicollinearity problem in this model.

\subsection{Regression results for relationship between HR integration and Employees productivity.}

A. Model summary

\begin{tabular}{|l|c|l|l|l|}
\hline Model & \multicolumn{1}{|c|}{$\mathbf{R}$} & $\mathbf{R}$ Square & \multicolumn{1}{|c|}{$\begin{array}{c}\text { Adjusted R } \\
\text { Square }\end{array}$} & STD. Error of Estimate \\
\hline 1 & $.775(\mathrm{a})$ & 0.601 & 0.335 & 3.45216 \\
\hline \multicolumn{2}{|l|}{ A predictors: ( constant), Reward management, performance management } \\
\hline
\end{tabular}


International Journal of Trend in Scientific Research and Development (IJTSRD) ISSN: 2456-6470

B. ANOVA(b)

\begin{tabular}{|l|l|c|l|l|l|l|}
\hline \multicolumn{1}{|c|}{ Model } & $\begin{array}{c}\text { sum of } \\
\text { squares }\end{array}$ & dff & mean square & F & sig \\
\hline \multirow{3}{*}{1} & Regression & 53.793 & 2 & 26.896 & 2.257 & $0.002(\mathrm{a})$ \\
\cline { 2 - 7 } & Residual & 35.732 & 3 & 11.917 & & \\
\cline { 2 - 7 } & Total & 89.545 & 5 & & & \\
\hline
\end{tabular}

C. Coefficients (a)

\begin{tabular}{|c|c|c|c|c|c|c|c|c|c|c|}
\hline \multirow[t]{2}{*}{ Model } & & \multicolumn{2}{|c|}{$\begin{array}{l}\text { Un- } \\
\text { standardized } \\
\text { coefficients }\end{array}$} & \multirow{2}{*}{\begin{tabular}{|l|}
$\begin{array}{l}\text { Standa- } \\
\text { rdized } \\
\text { coefficients }\end{array}$ \\
Beta
\end{tabular}} & \multirow[t]{2}{*}{$\mathrm{T}$} & \multirow[t]{2}{*}{ Sig } & \multicolumn{2}{|c|}{$\begin{array}{l}95 \% \text { confidence } \\
\text { interval for B }\end{array}$} & \multicolumn{2}{|c|}{$\begin{array}{l}\text { Collinearity } \\
\text { statistics }\end{array}$} \\
\hline & & $\bar{B}$ & \begin{tabular}{|l} 
Std \\
error
\end{tabular} & & & & $\begin{array}{l}\text { lower } \\
\text { Bound }\end{array}$ & $\begin{array}{l}\text { upper } \\
\text { bound }\end{array}$ & $\begin{array}{l}\text { Toleranc } \\
\mathrm{e}\end{array}$ & VIF \\
\hline \multirow[t]{3}{*}{1} & (Constant) & 53.153 & 4.144 & & 12.828 & 0.001 & 39.969 & 66.339 & & \\
\hline & $\begin{array}{l}\text { Performance } \\
\text { management }\end{array}$ & 0.366 & 0.253 & 0.563 & 1.445 & 0.004 & -0.44 & 1.173 & 0.878 & 1.139 \\
\hline & Reward mgt & 0.064 & 0.067 & -0.327 & -0.955 & 0.01 & -0.278 & 0.15 & 0.878 & 1.139 \\
\hline
\end{tabular}

\subsection{Summary of findings}

The first objective was to establish the major business strategies employed by transnational tea firms in Kenya. The study found that the overall generic strategy is cost leadership which is employed by $60 \%$ of the firms. Most of the tea produced by these tea firms is sold through the Mombasa tea auction where prices are determined by the buyers but not sellers therefore these firms have to take care of cost in order to maintain profit margin or improve it. Differentiation of products and focus on their current line and scale of production are other strategies applied in these firms but at lower percentage (20\%). Vertical integration and horizontal integration strategies are also applied in these firms. These firms apply vertical integration strategy by growing and transporting the raw material (green leaf) to their own factories instead of buying from out-growers. They grow their own firewood and produce their own hydro-electric power to reduce tea drying and processing costs. Integration strategy is applied by $35 \%$ of these tea firms.

The study has established that these firms seek to satisfy customer needs by providing high quality product and improving distribution channels. These firms therefore, seek to enhance their competitive advantage through maintaining high quality product, improved distribution channels for the tea not sold through auction and use of product differentiation strategy.

All these firms indicated that they intend to continuously improve methods and systems of work in order $\mathrm{t}$ sustain productivity through continuous training and development of employees and business reengineering and technological changes. The study has found Human resources as the core competitive advantage in these tea firms. These findings reinforce what Markowitch, et al (2002) concluded that, competition between companies are no longer dominated by access to capital, equipment, systems or location but the capability of the people which is created through continuous training and development.

The second specific objective was to establish the major human resource strategies applied in these tea firms.

Human resource strategies prescribe the overall direction the organization wishes to pursue in achieving its objectives through people( Wright and Snell 1998).HR strategies are those human resource activities used to support the firm's competitive strategy. The study found that the commonly applied HR strategies in these firms are performance management and reward management both used by all 
these firms $(100 \%)$. The study found that downsizing is used by $87 \%$ of these firms. There is a shift from purely hand picking of tea to a mixture of hand and mechanical harvesting. This is mainly for cost-cutting. Continuous learning and teamwork strategies were found to be important in these firms and was impressed by $86 \%$ of these firms. Training is gaining importance in these firms as demonstrated by increasing expenditure in training which tripled between 2006 and 2010) but this study found that this training was to fix the immediate competenceperformance gap as the firms are on a continuous downsizing trend. The study found that job rotation was given $43 \%$ importance, job redesigning $14 \%$ and recruitment $10 \%$. Job rotation here is used to develop supervisory and management level personnel for long term placement, job redesigning is necessary for business reengineering but recruitment is given very little importance due to current downsizing trend in these tea firms.

\section{Synergies created by strategic Fit}

The third objective of the study was to establish synergies created by strategic Fit between business strategies and human resource strategies in transnational tea firms in Kenya. According to Guest (1987), if human resources are integrated into strategic business plans, company's strategic plans are likely to be successfully implemented. Performance outcomes (synergies) in this study can be understood in terms of indicators such as employee commitment, employee flexibility and employee productivity. The study created three multiple regression model to test the usefulness of strategic fit to predict each of the three categorizations of synergies. The study found that $97 \%$ of the changes in employee commitment were caused by strategic Fit between business and HR strategies. Employee commitment was measured by such parameters as employee turn-over, absenteeism rates and grievance levels. The study further found that, there was no serious multicollinearity among the independent variables (strategic fit) thus confirming that employee commitment was one of the synergies caused by strategic fit. The study further found strong association between HR strategies and employee flexibility. Strategic fit was a significant predictor of employee flexibility. It found that $100 \%$ of the changes in employee flexibility were caused by strategic fit between business and HR strategies.
Employee flexibility was measured by such parameters as acceptance of change, teamwork and organizational learning. There was no serious multicollinearity among the independent variables (strategic fit) confirming employee flexibility as one of the synergies caused by strategic fit. Flexibility is critical for tea firms as it provides the capacity to manage the frequent and abrupt changes and enables the organization to be adaptive and responsive in the face of unanticipated pressures.

The study found that HR integration could be used to predict employee productivity. Vertical and horizontal fits are necessary. $60 \%$ of the changes in employee productivity were caused by HR integration.

\subsection{Conclusion}

HR strategies should be directly derived from business challenges in order to create solutions and add real value. HR strategy influences business strategy and in turn influenced by it. Tea firms use 'outside-in' approach in seeking to achieve strategic fit. The overall generic strategy applied by these tea firms is cost leadership. This is attributed to the fact that these firms export and sell tea through auction were the buyers are the ones who determine the price. Cost leadership, vertical integration, horizontal integration and diversification have been and will continue to be the most important business strategies in transnational tea firms in Kenya. HR strategies commonly used in these tea firms are continuous training, performance management and reward management. Here superior performance is rewarded thus motivating employees to enhance their productivity. The study also concluded that certain synergies are created when firms achieve a strategic fit between their business and HR strategies. These synergies include employee commitment, employee flexibility and employee productivity.

\section{Recommendations.}

The study recommended that the tea firms should identify other marketing strategies instead of relying more on selling their tea through auctioning in Mombasa. They should also embark more on different cost reduction strategies since their tea price is mostly determined by foreign buyers through auctioning.

\section{REFERENCES}

1. Adhikari, D. R (2009). Human resource development (HRD) for performance management; The case of Nepalese organizations, 
International Journal of productivity and performance management, $\mathrm{p}$ 306-324.

2. Armstrong, M. (2009), Armstrong's hand book of Human resource management practices, $11^{\text {th }}$ edition, London, Kogan page ltd

3. Armstrong. M. and Baron .A. (2007). A hand book ofstrategic HRM. $2^{\text {nd }}$ Edition Mumbai, Jaico Publishing House.

4. Armstrong, $M$ and Baron, A. (2006). Managing Performance: Performance management in action, Chartered institute of personnel and Development. CIPD House.

5. Cappell. P (1999). Employment practices and business strategy. New York, Oxford University Press.

6. Certon. S. C and Peter, J.P (1993). Strategic management: A focus on process. $2^{\text {nd }}$ Edition , Illinois, Richard D Irwin

7. Dimba. B. and K'obonyo, P (2009). The effects of strategic human resource management practices on performance of manufacturing multinational companies in Kenya. Moderating role of employee cultural orientation and mediating role of employees motivation. International Academy of African Business and development. 10 ${ }^{\text {th }}$ Anniversary international conference., May $9^{\text {th }}-3^{\text {rd }}$ (2009). Kampala.

8. Dyre. L. and Ericksen, J. (2005). Towards a strategic human resource management model of high reliability organization performance. International journal of human resource management.

9. Quest, D. (1987). Human Resource Management and Industrial Relations. International Journal of Human Resource Management 3:3, 497-521.

10. Hunger, J. D. and Wheelen T.L (2007). Essentials of strategic management $4^{\text {th }}$ Edition. New Delhi, Prentice Hall of India.

11. Hussey, D.E. (ed) (2000).International review of strategic management, john Wiley. New York.

12. Ireland, R. D, Hoskisson, R. E and Hitt, M.A. (2009). The management of strategy concepts and Cases, $8^{\text {th }}$ Edition. Mason, South Western Cengage learning.
13. Jackson, S. E and Schuler, R. S (2001). Managing Human Resource through strategic partnership, Editon, Mason, Ohio. Thomson, South-Western.

14. Katon. A. and Budhwar. P. (2006). Human Resource Management systems on Organizational performance: A test of Mediating model in the greek manufacturing context. International Journal of Human Resource Management. 17,7, 1223-1253.

15. Malik. F (2006). Effective Top management. Beyond the failure of Corporate Governance and shareholder value. Weinhein, Wiley. VCH.

16. Nel, P. S and Werner, A. (2002) Human Resource management, $5^{\text {th }}$ Edition. Cape Town. Oxford University press

17. Pearce, J. A and Robinson, R. B (2009). Strategic management. Foundation implementation and control, $11^{\text {th }}$ Edition. Boston, McGraw- Hill.

18. Pfeffer. J. (1994). Competitive advantages through people, Boston, MA, Harvard Business School Press.

19. Thomson. P. (2007). Making capital strategic dilemmas for HRM in Bolton, S.C and Maeve, H (Ed) (2007). Searching for the Human in Human Resource Management Theory, Practice and work place context, New York, Palegrave Macmillian

20. Thomson. A. A and Strickland, A.J 2993. Strategic management concepts and cases $7^{\text {th }}$ edition Boston, Mc Graw- hill

21. Tyson. S. (2006). Essentials of Human Resource Management. $5^{\text {th }}$ Edition, Oxford Elsevier. White. C. (2007). Strategic management. New York. Palgrave Macmillian

22. Wright. P.M and Snell. S. A (1998). Towards a Unifying Framework for Exploring Fit and Flexibility in strategic Human Resource Management. Academy of management Review. p 756-772

23. Markowitsch. J. Kollinger. I. Warmerdam. J. Moerel. H , KONRAD. J, Burel.C and Guile. D (2002).Competence and human resource development in multinational companies in three European Union member states; A comparative analysis between Australia, the Netherlands and United Kingdom. European center for Development of vocational training. 